\title{
APRESENTAÇÃO DO DOSSIÊ DESDEMOCRACIA, NEOLIBERALISMO E PRECARIEDADE
}

\section{PRESENTATION OF THE DOSSIER DEDEMOCRACY, NEOLIBERALISM AND PRECARIETY}

\author{
João Manuel de Oliveira ${ }^{1}$ \\ Marco Aurélio Máximo Prado ${ }^{2}$
}

\begin{abstract}
A contínua erosão das democracias ocidentais e o efeito dos desmontes provocado pela longa marcha do neoliberalismo (HALL, 2011) como ideologia econômica e como racionalidade apolítico-institucional têm possibilitado um movimento de privatização de bens, serviços e empresas públicas, bem como de um acirrado modo de subjetivação individualista, deixando os sistemas de proteção social e solidariedade radicalmente expostos, o que possibilitou aumentar ainda mais a precariedade de vários grupos sociais e populações. Como afirma Wendy BROWN (2015), a partir de um dado momento nos estados ocidentais, o neoliberalismo passou a tratar o tema da democracia como um custo acrescido, um exercício oneroso demais para ser mantido. Neste contexto, o neoliberalismo coloca-se como um inimigo das democracias liberais, dado que com a crescente privatização e com o aumento da escassez de bens públicos para continuar a privatizar, começa agora a voltar-se para áreas mais centrais na definição dos próprios estados (BROWN, 2019), tais quais: a gestão de forças de segurança, dos sistemas de encarceramento, a terceirização de serviços militares e de
\end{abstract}

\footnotetext{
${ }^{1}$ Doutor em Psicologia Social, Universidade Federal de Santa Catarina e ISCTE-Instituto Universitário de Lisboa. e-mail: joao.m.oliveira@gmail.com

${ }^{2}$ Doutor em Psicologia Social, Universidade Federal de Minas Gerais. e-mail: mamprado@gmail.com
} 
armamento e a produção de materiais que permitam operações de genocídio e políticas de extermínio.

Um outro caso é o da manipulação de eleições com o recurso à big data como forma de dirigir e referenciar o marketing político ou de fake news, patrocinadas por empresas privadas com interesses em garantir determinados resultados eleitorais para a implementação de seus projetos privatistas e também da ascensão pelas vias eleitorais de grupos ultraconservadores que buscam instituir um modelo de sociabilidade predominantemente cristão e familista aliado a uma privatização do público, a uma rebiologização das diferenças sociais, particularmente sexuais e por certo uma restrição dos direitos sociais e civis. Em termos geopolíticos, a sensação de que a correlação de forças se encontra em franca mudança, com a preponderância econômica chinesa, uma crise permanente ao império estadounidense que parece inevitável, mas que sempre se constitui um processo violento e bélico, a Europa em desagregação anunciada com a vitória da extrema direita, o processo Brexit em curso e os BRICS esvaziados da pujança econômica que lhes fora atribuída na primeira década dos anos 2000 .

Na América Latina vemos que, embora nas primeiras décadas desse século parecia ser um continente de resistências com novas vozes e personagens nas políticas governamentais, embora liberais e capitalizadas pelos mercados transnacionais, coexiste atualmente, o desmonte das democracias com a ascensão de movimentos conservadores, não sem resistências, uma vez que os ativismos anti-racistas e feministas interseccionais igualmente levantam performances e vozes por todo continente. Por outro lado, sérias ameaças às democracias, com uma extrema direita assumidamente neoliberal, autoritária e repressiva, que ganha eleições com presumidos inimigos externos graças à xenofobia ou com inimigos internos apelando ao racismo, heterossexismo, cisnormatividade, misoginia e classismo. Através de ódios dirigidos a determinados alvos, prediletos do ultraconservadorismo cristão e articulados para criar pânicos morais instalados por uma moral reacionária, estes regimes estão conseguindo destituir todo o esforço de políticas públicas arduamente conquistadas por movimentos sociais em décadas de luta, que construíram sujeitos políticos com determinados efeitos nas políticas de identidade. 
O processo de desdemocratização em curso, de tentativas concertadas de diminuir a qualidade e a densidade das democracias, quer através da redução do impacto das suas políticas públicas, quer através das inibições à participação da população no acesso ao que é público, incluindo decisões, direitos e benefícios sociais, tem como decorrência a instalação de um processo longo de precarização. Este processo acostuma e aclimatiza uma população à insegurança e à desesperança, dizimando as redes de apoio social e do Estado à população que lutam contra a precariedade, posição politicamente induzida em que determinadas populações se encontram diferencialmente vulneráveis à exposição à violência (BUTLER, 2018), biopolítica (FOUCAULT, 2008) e necropolítica (MBEMBE, 2018). Foi a partir destas propostas que lançamos a chamada de artigos para este dossiê temático que conta com 3 trabalhos distintos, após processo editorial, do qual queremos mencionar e agradecer o trabalho dos revisores/as anônimos/as, fundamentais para o processo.

Leomir Cardoso Hilário (UFS), que no seu Ascensão e colapso da razão instrumental neoliberal, nos apresenta o panorama generalizado do neoliberalismo enquanto razão instrumental, conceito de Adorno e Horkheimer. Este trabalho revisita o percurso histórico da racionalidade neoliberal e ajuda a situar os processos de produção de subjetividades como o empresário de si mesmo até ao presente estado de destruição necropolítica.

Neste panorama, o trabalho de Lorena Rodrigues Tavares de Freitas, intitulado Desumanização, reconhecimento e resistência na América Latina e Caribe: uma articulação entre a teoria da precariedade de Judith Butler e o feminismo decolonial de María Lugones (UNILA) apresenta alguns conceitos centrais para entender os processos de desumanização e de maximização da precariedade. Com efeito tanto o feminismo interseccional como a teoria decolonial têm ofertado um léxico de conceitos fundamentais para entender esses efeitos junto de populações específicas, precisamente aquelas colocadas enquanto populaçõesalvo dessa ofensiva, os grupos historicamente subalternizados nas sociedades latinoamericanas: pobres, mulheres, povos originários , grupos racializados e LGBTI (Lésbicas, Gays, Bissexuais, Travestis, Transexuais, Transgêneros e Intersexos). 
Daniel Medeiros de Freitas (UFMG), Marcela Silvano Brandão (UFMG) e Natacha Araújo Rocha (UFMG) apresentam o trabalho Cartografias Indisciplinares: experiência extensionista nas lutas urbanas de Belo Horizonte-MG que nos brinda um conjunto de experiências extensionistas do grupo de pesquisa Indisciplinar, da Escola de Arquitetura da UFMG, junto às lutas urbanas. Estes trabalhos integram diversos especialistas no apoio aos movimentos sociais de ativismo urbanos e de ocupação e incluem a importante tentativa de tradução dos discursos de técnicos e do poder público, desvelando os seus discursos, muitas vezes opacos para o público.

Estes trabalhos traduzem algumas das preocupações que tínhamos para este dossiê e que não se esgotam aqui, antes esperamos que da sua leitura surjam inquietações e estranhamentos que possam conduzir a mais reflexão e luta pela democratização radical de nossas sociedades.

\section{REFERÊNCIAS}

BROWN, Wendy. Undoing the Demos: Neoliberalism's Stealth Revolution. New York: Zone Books, 2015

BROWN, Wendy. In the Ruins of Neoliberalism: the Rise of Antidemocratic Politics in the West. New York: Columbia University Press, 2019.

BUTLER, Judith. Corpos em aliança e a política das ruas: notas para uma teoria performativa de assembleia. 2 ed. Rio de Janeiro: Civilização Brasileira, 2018

FOUCAULT, Michel. O Nascimento da biopolítica. São Paulo: Martins Fontes, 2008.

HALL, Stuart. The neoliberal Revolution - Thatcher, Blair, Cameron - the long march of neoliberalism continues. Soundings, 48, 9-27, 2011.

MBEMBE, Achille. Necropolítica. S. Paulo: n-1, 2018. 